Research Article

\title{
Does Service Failure Context Matter? Customers' Response to Service Recovery
}

\author{
Raquel Reis Soares ${ }^{1}$ and João F. Proença ${ }^{2}$ \\ ${ }^{1}$ University of Aveiro, Aveiro, Portugal \\ ${ }^{2}$ University of Porto, FEP-School of Economics and Management, Porto and \\ University of Lisbon, ADVANCE Research Center, Lisbon, Portugal
}

Correspondence should be addressed to: Raquel Reis Soares; raquel.reis@ua.pt

Received date: 10 March 2014; Accepted date: 1 July 2014; Published date: 23 June 2015

Academic Editor: Naima Bakor Bogari

Copyright (C) 2015 Raquel Reis Soares and João F. Proença. Distributed under Creative Commons CCBY 4.0

\begin{abstract}
Because service failures are difficult to avoid in the services context due to their characteristics, firms need to offer an adequate service recovery to compensate customers. Customer behavior may be affected either by the failure or its recovery. The purpose of this study is to explore the impact of service failure severity in customers' post-recovery behavior. The study comprises a sample of 40,813 customers, representing customers who had experienced a problem with the service provider and customers who had not. Empirical results showed that service failure severity has a significant negative influence in customers' post-recovery repurchase behavior. Nevertheless, the influence differs across customers' relationship age with the service. Additionally, they also provide evidence of when service recovery paradox is more likely to occur. This study contributes with relevant insights for practitioners. Since failure severity affects negatively customers' post-recovery repurchase behavior, the classification of service failures by degree of severity is commended. Hence, firms should adopt different service recovery strategies depending on failures severity degree and customers' relationship age with the firm. Customers' segmentation should consider these characteristics in order to enhance complaints management and customer loyalty.
\end{abstract}

Keywords: Service failure severity, Post-recovery behavior, Gender, Relationship age

\section{Introduction}

In a relationship-oriented era, satisfying customers is crucial for service providers, not only to enhance customers' satisfaction, but also to ensure a long term relationship with them. However, firms face situations where customers are dissatisfied due to the occurrence of a failure. A flawless service is hard to achieve despite being the objective of firms (Boshoff, 1997; Kuo and Wu,
2012). Recognizing the variety of failures that can occur and the effective recovery strategy to each one are the challenges of firms (Craighead et al., 2004; Kuo et al., 2011). Being aware of the potential negative impact service failures have on customer loyalty, recovery techniques can work as second opportunities to service providers deliver a positive experience (Hoffman et al., 1995). In this context, an effective recovery could lead to a 
paradoxical situation: a customer who experiences a failure may become more satisfied than those who did not experience any problem. It is the so-called service recovery paradox phenomenon (Ok et al., 2007) and despite its potential benefits, only a few studies have analyzed it directly (Maxham, 2001).

The current research extends previous studies by studying the role of failure context, i.e. failure type and the failure severity and their impact on customers' post-recovery behavior, i.e. on repurchase behavior. The research aims first to assess the role of failure type and failure severity in customers' reactions. Second, it seeks to investigate the role of compensation, gender and relationship age as potential moderating variables in the aforementioned relationships. Finally, it is analyzed whether service recovery paradox exists in a mobile telecommunications setting, which variables contribute for its occurrence and how they influence it.

\section{Theoretical Framework}

\section{Service Failure-Recovery Context}

A service failure is defined in the literature as an incident occurred during the service delivery which represents a loss for customers and leads to customers dissatisfaction (Smith et al., 1999; Maxham, 2001). In fact, providing a service without failures is the firms' objective, however due to their specific characteristics it is almost impossible when we talk about services (Michel and Meuter, 2008). Hence, a service failure is considered a significant motivator of customers' switching behavior (Mccollough et al., 2000).

Service recovery is perceived as a process by which a firm tries to rectify a breach in the service (Maxham, 2001). This process should be faced by firms as a strategic marketing variable that can potentiate an increase in customer satisfaction and retention (Hart et al., 1990).

A good service recovery is crucial to enhance the relationship with dissatisfied customers (Tax et al., 1998; Maxham, 2001) and to create conditions for the occurrence of the service recovery paradox. In the last decade, service recovery paradox phenomenon has become a key focus in services marketing literature (De Matos et al., 2007), regarding a situation where customers, after a firm's recovery effort, will be as satisfied as, or even more than those had not experienced any problem (Smith and Bolton, 1998; Mccollough et al., 2000). Although this is a significant phenomenon for academics and practitioners, due to the opportunity it offers to achieve higher levels of customer satisfaction (Smith et al., 1999; Priluck and Lala, 2009), literature has found mixed results: one school of studies confirms the phenomenon existence (Boshoff, 1997; Smith and Bolton, 1998; Michel, 2001; Michel and Meuter, 2008), while the other reveals the lack of evidence of such phenomenon and assumes it does not exist (Bolton, 1998; Mccollough et al., 2000; Andreassen, 2001; Maxham, 2001; Shapiro et al., 2006). Weun et al., (2004) on their study noted that failure severity could influence the service recovery paradox, mainly when less severe failures occurred. Contrary to weak failures, a severe one, even with an exceptionally response from the service provider, can cause a situation without equity and hard to restore.

\section{The Impact of Service Failure Context on Customers' Behavioral Outcomes}

We can find two distinct service failure types in the literature (Bitner et al., 1990; Keaveney, 1995). Outcome failures, related to incidents occurred with the service core (e.g. unavailability of the service) and process failures, related to service delivery failures (e.g. a call center employee not polite). The type of failure and its associated loss influence customer evaluations of the service (Smith et al., 1999). While an outcome failure has an economic loss to customers, a process failure brings social loss. Although services marketing literature does not provide information about which failure type has more impact on customers' behavioral responses, Smith et al., (1999) suggested that customers' evaluations of service will 
differ according to the failure type occurred, since each one represents a different category of loss. Therefore, we expect that when an outcome failure occurs, customers' perceptions of distributive justice will be restored by recovery economic attributes, such as a monetary compensation or a fast resolution. Smith et al., (1999) found that process failures have a higher impact on customer dissatisfaction than outcome failures. Hence, we proposed the following hypotheses:

H1: Process failures will have a more negative influence on customers' repurchase than outcome failures.

H2: When a compensation is offered, the negative impact of an outcome failure on customers' repurchase will be lower than the negative impact of a process failure.

The lack of information about the role of service severity in the service recovery process is recognized in the literature and the need to consider this construct in services marketing literature research is stressed (Weun et al., 2004). Therefore, previous studies argued that service failure severity influences customers' satisfaction (Smith et al., 1999; Weun et al., 2004), assuming that failures classification is very important for firms (Kuo et al., 2011). Service failure severity is the customer's perceived intensity of a critical incident and there is a positive relationship between customers' perceived loss and failure severity (Weun et al., 2004; Huang, 2008): as failure severity increases, customers' perceived loss decreases. Service recovery expectations may vary positively with the failure severity (Bitner et al., 1990; Hoffman et al., 1995) and even after an adequately recovery, a severe failure (outcome or process) will produce a perceived loss (Weun et al., 2004). Prior studies argued that the level of customer satisfaction decreases as failure severity increases (Gilly and Gelb, 1982; Hoffman et al., 1995) and the failure severity influences the customers' evaluation of a service provider (Weun et al., 2004). As failure severity increases, it will be more difficult to satisfy customers through service recovery strategies (Smith and Bolton, 1998; Mattila, 1999; Magnini et al., 2007). Customers' zone of tolerance also varies depending on the context, and the more severe the service failure is the less tolerant customers will be (Zeithaml et al., 1993). We expect that failure severity will negatively impact customers' postrecovery behavior, namely repurchase. Then, the following hypotheses were formulated:

H3: Severe failures will have a negative influence on customers' repurchase.

H4: Weak failures will have a lower negative impact on customers' repurchase when compensation is offered.

Some researchers argued that gender can modify projected behavior patterns (Homburg and Giering, 2001; Mittal and Kamakura, 2001; White and Dahl, 2006). Thus, a deeper analysis of the potential moderating role of gender on customers' repurchase behavior is called for research (Lin, 2010). They pointed out that male customers are more demanding and objective oriented (Cambra-Fierro et al., 2012), expecting short-term results than female customers (Iacobucci and Ostrom, 1993). Since females are more socially oriented (Cambra-Fierro et al., 2012), they tend to be more loyal than male customers (Iacobucci and Ostrom, 1993; Homburg and Giering, 2001; Mittal and Kamakura, 2001). It is expected that male customers will be more sensitive to severe failures, i.e. an increase on failure severity will represent a growth on customers' dissatisfaction and, consequently, a decrease on repurchase. This expectation is reflected in the next hypotheses:

H5: The negative impact of severe failures on customers' repurchase behavior will be higher for male customers.

H6: The negative impact of process failures on customers' repurchase behavior will be higher for female customers.

Relational characteristics such as customer-service relationship duration/age can represent switching 
barriers and work as competitive advantages for firms. They are especially relevant in contractual services (Seiders et al., 2005). A negative relationship between service failure severity and relationship age with the service provider is recognized in previous studies (Weun et al., 2004). Due to the customer's perception of a loss experienced, the customer relationship age will decrease (Bolton, 1998). When a severe failure occurs, customers are less likely to identify themselves with service providers' values and the desire of maintaining the relationship decreases (Keaveney, 1995). Nevertheless, the duration of the customer/firm relationship increases customers' tolerance (Palmer et al., 2000). After a problem with the service provider, customers' perceived level of equity will increase as the relationship age increases. Thus, it is expected that service failure severity has a higher negative impact on customers' response when relationship age is lower. The last hypotheses are formulated:

H7: The negative impact of severe failures on customers' repurchase behavior will be higher for beginner customers.

H8: The negative impact of process failures on customers' repurchase behavior will be higher for beginner customers.

\section{Method}

A firm's database in the context of the Portuguese mobile internet industry was selected to test the hypotheses and data collection was made, by convenience, in one of the major firms of the industry. The database included the customers' telephone calls during the year 2012, i.e. a total of 40,813 customers who contacted (those who had experienced a service failure and those who had not - control group) the call center. The strategy behind this choice has been the competitiveness in the telecommunications sector and because such a competitive context underlines the relevance of a deep understanding of customers' characteristics. Literature has called for more research on effective repurchase behavior (Chang and Polonsky, 2012). Seiders et al., (2005) considered the actual repurchase behavior as repeated visits to the service and/or an increased amount spent on the service.

\section{Construct Operationalization and Measures}

In this research, repurchase is measured as follows: customer keeps the service active (the account is active) and increases the amount spent in the service (average amount spent).

Relationship age with the service considered that the service contract length is usually 24 months. The analyzed service in this study has a contractual loyalty of 24 months and customers who want to change the service provider before the end of this period have to pay penalties. Beginner customers are those who have a shorter relationship with the service provider (less than 24 months) and advanced customers have a longer relationship (more than 24 months), i.e. they do not have the obligation to remain in a relationship with this service provider. A three-item scale, adapted from Hess et al., (2003), classified each service failure severity in severe, moderate or weak. A supervisor of the Complaint Management Service confirmed the accuracy of this distribution. Then, variables were divided in groups: compensation (with; without); failure type (outcome failure; process failure); failure severity (weak; moderate; severe) and relationship age (beginner customers; advanced customers).

\section{Results}

Through logistic regression analysis we found that failure type and failure severity ( $p=0.000)$ were significant predictors of customers' repurchase behavior. Although both types of failures (process and outcome) were found to be significant predictors of customers' response (Table $1)$, results showed that a customer who experienced process failures were more likely to repurchase (odds ratio $=3.818$ ). So, Hypothesis 1 is not supported because outcome failures had a more negative impact on repurchase behavior than process failures. Compensation was proved 
to moderate the relationship between failure type and repurchase, but not as we expected. In fact, outcome failures showed lower positive impact on repurchase (odds ratio $=1.112$ ) than process failures (odds ratio $=1.920$ ), when compensations were offered to customers. So, Hypothesis 2 is not supported.

Apart from the proposed hypotheses, further analyses were conducted to analyze whether the service recovery paradox occurs. Then, we performed a Chi Square test to examine if there is a relationship between variables and to understand how the relationship varies across groups of customers. Results confirmed the existence of the service recovery paradox phenomenon: a relationship between customers who experienced a service failure with the service provider and repurchase was encountered $\left(X^{2}=2584.872 ; p<0.001\right)$ since the $p$-value is $<0.05$, confirming the association. Moreover, this relationship between the aforementioned variables got a Phi coefficient of 0.252 , statistically supporting the positive relationship. Though it is a strong association: customers who experienced a failure and subsequently a recovery were more willing to repurchase $(37.7 \%)$ than those who did not experience any failure $(15 \%)$.
As shown in Table 2, the odds of a customer who experienced a weak failure to have repurchased were 175.294 times higher than in the case of no failure. Results showed that failure severity negatively impacted repurchase behavior, suggesting that customers who experienced more severe failures were less likely to repurchase (odds ratio increased from 4.017 to 175.294 when we moved from severe to weak failures). Then, service recovery paradox is more likely to occur when weak failures happen. According to these results, Hypothesis 3 was supported.

The interaction between failure severity and compensation presented a significant contribution to the model $(\mathrm{p}=0.000)$. Customers are more likely to repurchase and service recovery paradox phenomenon is more likely to take place when compensation is offered due to a weak critical incident, supporting Hypothesis 4: the odds ratio when compensation was not offered was 0.033 for weak failures; 1.118 for moderate failures; and of 1.987 for severe failures.

The interactions between gender and failure type ( $p=0.615)$ and gender and failure severity (0.911) had no statistical significance explaining variations in repurchase ( $p>0.05$ ). So, Hypotheses 5 and 6 were not supported. 
Table 1: Results of Logistic Analysis (Failure Type as Independent Variable)

\begin{tabular}{|c|c|c|c|c|c|}
\hline & \multirow[b]{2}{*}{ B (SE) } & \multirow[b]{2}{*}{$\mathrm{P}$} & \multicolumn{3}{|c|}{ 95\% CI for Odds Ratio } \\
\hline & & & Lower & \begin{tabular}{|l} 
Odds \\
Ratio \\
\end{tabular} & Upper \\
\hline Type & & $0.000^{*}$ & & & \\
\hline type (Process) & $1.340(0.155)$ & $0.000^{*}$ & 2.820 & 3.818 & 5.169 \\
\hline type (Outcome) & $1.082(0.034)$ & $0.000^{*}$ & 2.758 & 2.951 & 3.157 \\
\hline type by Gender & & 0.615 & & & \\
\hline type (Process) by gender (Male) & $-0.175(0.191)$ & 0.360 & 0.577 & 0.839 & 1.221 \\
\hline type (Outcome) by gender (Male) & $0.014(0.038)$ & 0714 & 0.941 & 1.014 & 1.093 \\
\hline type by $r_{-}$age & & $0.000^{*}$ & & & \\
\hline type (Process) by r_age (Beginner) & $0.147(0.215)$ & 0.496 & 0.759 & 1.158 & 1.765 \\
\hline type (Outcome) by r_age (Beginner) & $0.426(0.046)$ & $0.000^{*}$ & 1.400 & 1.531 & 1.675 \\
\hline type by Compensation & & $0.000^{*}$ & & & \\
\hline type (Process) by compensation (Without) & $0.652(0.205)$ & $0.001^{*}$ & 1.284 & 1.920 & 2.869 \\
\hline type (Outcome) by compensation (Without) & $0.106(0.043)$ & 0.014 & 1.022 & 1.112 & 1.210 \\
\hline Constant & $-1.731(0.017)$ & $0.000^{*}$ & & 0.177 & \\
\hline
\end{tabular}

Note: $R^{2}=1.497$ (Hosmer \& Lemeshow), 0.061 (Cox \& Snell), 0.094 (Nagelkerke). Model $X^{2}(8)=2562.88 ; p<0.01 .{ }^{*} p<0.01$.

Source: SPSS

Relationship age and failure severity interaction was another significant predictor of customers' repurchase behavior ( $p=0.000)$. However, the odds of an advanced customer to repurchase when a moderate failure occurs were only 0.648 times than for beginner customers and the interaction when a weak and a severe failure occur had no statistical significance ( $\mathrm{p}>0.05)$, rejecting Hypothesis 7 . Moreover, relationship age and failure type interaction contributed to the model $(\mathrm{p}=$
0.000). As shown in Table 4.1, a beginner customer was more willing to repurchase when experienced an outcome failure (odds ratio $=1.531)$. Since this interaction was not statistically significant for process failures $(p=0.496)$, not contributing to this model, Hypothesis 8 was rejected.

To sum up, eight hypotheses were tested and their results are summarized in Table 3. 
Table 2: Results of Logistic Analysis (Failure Severity as Independent Variable)

\begin{tabular}{|c|c|c|c|c|c|}
\hline & \multirow[b]{2}{*}{$\mathrm{B}(\mathrm{SE})$} & \multirow[b]{2}{*}{$\mathrm{p}$} & \multicolumn{3}{|c|}{ 95\% CI for Odds Ratio } \\
\hline & & & Lower & $\begin{array}{l}\text { Odds } \\
\text { Ratio }\end{array}$ & Upper \\
\hline Severity & & $0.000^{*}$ & & & \\
\hline severity (Weak) & $\begin{array}{r}5.166 \\
(0.859)\end{array}$ & $0.000^{*}$ & 32.583 & 175.294 & 943.071 \\
\hline severity (Moderate) & $\begin{array}{r}1.498 \\
(0.051)\end{array}$ & $0.000^{*}$ & 4.046 & 4.471 & 4.941 \\
\hline severity (Severe) & $\begin{array}{r}1.391 \\
(0.224)\end{array}$ & $0.000^{*}$ & 2.590 & 4.017 & 6.232 \\
\hline compensation by severity & & $0.000^{*}$ & & & \\
\hline compensation (Without) by severity (Weak) & $\begin{array}{r}-3.399 \\
(0.775)\end{array}$ & $0.000^{*}$ & 0.007 & 0.033 & 0.153 \\
\hline $\begin{array}{l}\text { compensation (Without) by severity } \\
\text { (Moderate) }\end{array}$ & $\begin{array}{r}0.111 \\
(0.044)\end{array}$ & 0.011 & 1.026 & 1.118 & 1.218 \\
\hline compensation (Without) by severity (Severe) & $\begin{array}{r}0.687 \\
(0.198)\end{array}$ & $0.001^{*}$ & 1.347 & 1.987 & 2.931 \\
\hline gender by severity & & 0.911 & & & \\
\hline gender (Male) by severity (Weak) & $\begin{array}{r}0.216 \\
(0.487)\end{array}$ & 0.664 & 0.469 & 1.241 & 3.284 \\
\hline gender (Male) by severity (Moderate) & $\begin{array}{r}0.009 \\
(0.039)\end{array}$ & 0.818 & 0.936 & 1.009 & 1.088 \\
\hline gender (Male) by severity (Severe) & $\begin{array}{r}-0.101 \\
(0.186)\end{array}$ & 0.586 & 0.628 & 0.904 & 1.301 \\
\hline r_age by severity & & $0.000^{*}$ & & & \\
\hline r_age (Beginner) by severity (Weak) & $\begin{array}{r}-0.162 \\
(0.520)\end{array}$ & 0.755 & 0.307 & 0.850 & 2.357 \\
\hline r_age (Beginner) by severity (Moderate) & $\begin{array}{r}-0.434 \\
(0.046)\end{array}$ & $0.000^{*}$ & 0.592 & 0.648 & 0.710 \\
\hline r_age (Beginner) by severity (Severe) & $\begin{array}{r}-0.077 \\
(0.209)\end{array}$ & 0.715 & 0.615 & 0.926 & 1.396 \\
\hline Constant & $\begin{array}{r}-1.731 \\
(0.017) \\
\end{array}$ & $0.000 *$ & & 0.177 & \\
\hline
\end{tabular}

Note: $R^{2}=1.254$ (Hosmer \& Lemeshow), 0.063 (Cox \& Snell), 0.098 (Nagelkerke). Model $X^{2}(8)=2675.725 ; p<0.01{ }^{*} p<0.01$.

Source: SPSS. 
Table 3: Hypotheses Validation

\begin{tabular}{|l|c|}
\hline $\begin{array}{l}\text { H1: Process failures will have a more negative influence on } \\
\text { customers' repurchase than outcome failures. }\end{array}$ & Not supported \\
\hline $\begin{array}{l}\text { H2: When a compensation is offered, the negative impact of } \\
\text { an outcome failure on customers' repurchase will be lower } \\
\text { than the negative impact of a process failure. }\end{array}$ & Not supported \\
\hline $\begin{array}{l}\text { H3: Severe failures will have a negative influence on } \\
\text { customers' repurchase. }\end{array}$ & Supported \\
\hline $\begin{array}{l}\text { H4: Weak failures will have a lower negative impact on } \\
\text { customers' repurchase when compensation is offered. }\end{array}$ & Supported \\
\hline $\begin{array}{l}\text { H5: The negative impact of severe failures on customers' } \\
\text { repurchase behavior will be higher for male customers. }\end{array}$ & Not supported \\
\hline $\begin{array}{l}\text { H6: The negative impact of process failures on customers' } \\
\text { repurchase behavior will be higher for female customers. }\end{array}$ & Not supported \\
\hline $\begin{array}{l}\text { H7: The negative impact of severe failures on customers' } \\
\text { repurchase behavior will be higher for beginner customers. }\end{array}$ & Not supported \\
\hline $\begin{array}{l}\text { H8: The negative impact of process failures on customers' } \\
\text { repurchase behavior will be higher for beginner customers. }\end{array}$ & \\
\hline
\end{tabular}

\section{Discussion and Conclusions}

The findings of our research confirm that service failures context (failure type and failure severity) affect customer behavioral outcome, however not completely in the way it was expected. Our findings do not confirm the moderating effect of gender on the relationship between failure context (failure severity and failure type) and customers' repurchase behavior. It became clear that severe failures can cause huge damage in the customer-firm relationship, especially when customers have a longer relationship with the service provider. Contrary to what is suggested by Palmer et al., (2000).

Our additional analyses showed evidence of the service recovery paradox phenomenon which was proved to be more likely to occur when a beginner customer experienced a more severe failure and when an advanced customer experienced a weak failure. Up to date, a huge number of studies have investigated service failures and recoveries, but few have empirically examined the service recovery paradox phenomenon in the current model of service recovery (Mccollough et al., 2000; De Matos et al., 2007). However, contradictory results in service recovery paradox research offer a stimulus to further research on it. We hope this research contributes to clarify not consistent studies, proving service recovery paradox and showing in which conditions it can arise.

From a managerial perspective, since service failures are unavoidable and influence post-recovery repurchase behavior, an effective service recovery management is essential to ensure service recovery paradox phenomenon. Results provided evidences of service recovery paradox presence in this setting: it is more likely to occur when less severe failures happen; for those who have a shorter relationship age with the firm, due to an outcome failure; and when compensation is offered to recovery from a weak failure as well. In fact, failure severity influences negatively customers' post-recovery behavior, which is consistent with other studies (Hoffman et al., 1995; Mattila, 1999; Magnini et al., 2007). Consequently, it negatively impacts on the existence of the service recovery paradox. The classification of service failures by degree of severity may provide firms additional insights into customers' responses (Smith et al., 1999). Thus, understanding the severity level of a service failure is important to design the best recovery strategies (Hart et al., 1990). We found that when failure severity was higher, repurchase had a more negative behavior. Gender is not a moderator of the 
relationship between failure context and customers' repurchase behavior in the service recovery model which is inconsistent with other researchers' studies such as Mattila (2010), Homburg and Giering (2001), Mittal and Kamakura (2001). Relationship age also have a moderating role in the relationship between failure severity and repurchase. Customers with a shorter relationship age with the service provider are more likely to repurchase. In the studied firm, the length of the contract is 24 months. Having occurred a severe or moderate failure, after this period, customers proved to be more likely to abandon the service and not to repurchase. Paying attention to these variables role in the service recovery paradox phenomenon and in this specific context, one can potentiate a better complaint management and contribute to the increasing of customer loyalty.

\section{Limitations and Further Research}

The present research found some limitations. Although literature called for research in sectors less examined (CambraFierro et al., 2012), we have only analyzed the Portuguese internet mobile sector. So, generalizing to other service industries may not be appropriate and future research in other industries would be useful to test the similarity of the findings. De Matos et al. (2007), through their metaanalysis, argued that service recovery paradox is more likely to be found in the hospitality industry due to its high-contact characteristic. Managers should be aware of these differences across service industries. In addition, because a quantitative database has been used, customers' perceptions and emotional involvement were not tested. Further, not all researchers apply the same theoretical definition of service recovery paradox neither the same operationalization. We compared a recovery group with a nonfailure control group, i.e. we used a between-subjects approach (Mccollough et al., 2000) instead of a within-subjects approach (Maxham, 2001). Mixed findings about service recovery paradox could be justified by these methodological differences found in previous studies.
Finally, the moderator role of other customers' characteristics such as age and education may bring important findings, as well. For example, identifying how severity varies according each type of failure. This would allow managers to implement strategies to reduce the occurrence of those types of failures.

\section{Acknowledgment}

The author Joao Proença thanks Fundação para a Ciência e Tecnologia (FCT Portugal) for financial support to ADVANCE by the Multi-Year Funding Program for R\&D Units. This paper was financed by FCT: Project Pest OE/EGE/UI4027/2011.

\section{References}

1.Andreassen, T. W. (2001). "From Disgust to Delight Do Customers Hold a Grudge?," Journal of Service Research, Vol. 4 (1), pp. 39-49.

2.Bitner, M. J., Booms, B. H. \& Tetreault, M. S. (1990). "The Service Encounter: Diagnosing Favorable and Unfavorable Incidents," Journal of Marketing, Vol. 54 (January), pp. 71-84.

3.Bolton, R. N. (1998). "A Dynamic Model of the Duration of the Customer's Relationship with a Continuous Service Provider: The Role of Satisfaction," Marketing Science, Vol. 17 (1), pp. 45-65.

4.Boshoff, C. (1997). "An Experimental Study of Service Recovery Options," International Journal of Service Industry Management, Vol. 8 (2), pp. 110-130.

5.Cambra-Fierro, J., Berbel-Pineda, J. M., Ruiz-Benítez, R. \& Vázquez-Carrasco, R. (2012). "Analysis of the Moderating Role of the Gender Variable in Service Recovery Processes," Journal of Retailing and Consumer Services, Vol. In press, pp. 1-11.

6.Chang, Y. W. \& Polonsky, M. J. (2012). "The Influence of Multiple Types of Service Convenience on Behavioral Intentions: The Mediating Role of Consumer Satisfaction in a Taiwanese Leisure Setting," International 
Journal of Hospitality Management, Vol. 31 (1), pp. 107-118.

6.Craighead, C. W., Karwan, K. R. \& Miller, J. L. (2004). "The Effects of Severity of Failure and Customer Loyalty on Service Recovery Strategies," Production and Operations Management, Vol. 13 (4), pp. 307-321.

7.De Matos, C. A., Henrique, J. L. \& Rossi, C. A. V. (2007). "Service Recovery Paradox: A Meta-Analysis," Journal of Service Research, Vol. 10 (1), pp. 60-77.

8.Gilly, M. C. \& Gelb, B. D. (1982). "PostPurchase Consumer Processes and the Complaining Consumer," Journal of Consumer Research, Vol. 9 (December), pp. 323-328.

9.Hart, C. W., Heskett, J. L. \& Sasser, W. E. J. (1990). "The Profitable Art of Service Recovery," Harvard Business Review, Vol. 68 (July-August), pp. 148-156.

10.Hess, R. L., Ganesan, S. \& Klein, N. M. (2003). "Service Failure and Recovery: The Impact of Relationship Factors on Customer Satisfaction," Journal of the Academy of Marketing Science, Vol. 31 (2), pp. 127-145.

11.Hoffman, K. D., Kelley, S. W. \& Rotalsky, H. M. (1995). "Tracking Service Failures and Employee Recovery Efforts," Journal of Services Marketing, Vol. 9 (2), pp. 49-61.

12.Homburg, C. \& Giering, A. (2001). "Personal Characteristics as Moderators of the Relationship Between Customer Satisfaction and Loyalty-An Empirical Analysis," Psychology \& Marketing, Vol. 18 (1), pp. 43-66.

13.Huang, W.-H. (2008). "The Impact of Other-Customer Failure on Service Satisfaction," International Journal of Service Industry Management, Vol. 19 (4), pp. 521-536.

14.Iacobucci, D. \& Ostrom, A. (1993). "Gender Differences in the Impact of Core and Relational Aspects of Services on the Evaluation of Service Encounters," Journal of Consumer Psychology, Vol. 2 (3), pp. 257286.

15.Keaveney, S. M. (1995). "Customer Switching Behavior in Service Industries: An Exploratory Study," Journal of Marketing, Vol. 59 (2), pp. 71-81.

16.Kuo, Y. F. \& Wu, C. M. (2012). "Satisfaction and Post-Purchase Intentions with Service Recovery of Online Shopping Websites: Perspectives on Perceived Justice and Emotions," International Journal of Information Management, Vol. 32 (2), pp. 127-138.

17.Kuo, Y. F., Yen, S. T. \& Chen, L. H. (2011). "Online Auction Service Failures in Taiwan: Typologies and Recovery Strategies," Electronic Commerce Research and Applications, Vol. 10 (2), pp. 183-193.

18.Lin, W.-B. (2010). "Service Recovery Expectation Model - from the Perspectives of Consumers," The Service Industries Journal, Vol. 30 (6), pp. 873-889.

19.Magnini, V. P., Ford, J. B., Markowski, E. P. \& Honeycutt Jr, E. D. (2007). "The Service Recovery Paradox: Justifiable Theory or Smoldering Myth?," Journal of Services Marketing, Vol. 21 (3), pp. 213-225.

20.Mattila, A. S. (1999). "An Examination of Factors Affecting Service Recovery in a Restaurant Setting," Journal of Hospitality and Tourism Research, Vol. 23 (3), pp. 284298.

21.Mattila, A. S. (2010). "Do women like options more than men? An Examination in the Context of Service Recovery," Journal of Services Marketing, Vol. 24 (7), pp. 499508.

22.Maxham, J. G. (2001). "Service Recovery's Influence on Consumer Satisfaction, Positive Word-of-Mouth, and Purchase Intentions," Journal of Business Research, Vol. 54 (1), pp. 11-24.

23.Mccollough, M. A., Berry, L. L. \& Yadav, M. S. (2000). "An Empirical Investigation of Customer Satisfaction After Service Failure 
and Recovery," Journal of Service Research, Vol. 3 (2), pp. 121-137.

24.Michel, S. (2001). "Analyzing Service Failures and Recoveries: A Process Approach," International Journal of Service Industry Management, Vol. 12 (1), pp. 2033.

25.Michel, S. \& Meuter, M. L. (2008). "The Service Recovery Paradox: True but Overrated?," International Journal of Service Industry Management, Vol. 19 (3-4), pp. 441-457.

26.Mittal, V. \& Kamakura, W. (2001). "Satisfaction, Repurchase Intent and Repurchase Behaviour: Investigating the Moderating Effect of Customer Characteristics," Journal of Marketing Research, Vol. 38, pp. 131-142.

27.0k, C., Back, K. J. \& Shanklin, C. W. (2007). "Mixed Findings on the Service Recovery Paradox," Service Industries Journal, Vol. 27 (6), pp. 671-686.

28.Palmer, A., Beggs, R. \& KeownMcmullan, C. (2000). "Equity and Repurchase Intention Following Service Failure," Journal of Services Marketing, Vol. 14 (6), pp. 513-528.

29.Priluck, R. \& Lala, V. (2009). "The Impact of the Recovery Paradox on Retailer-Customer Relationships," Managing Service Quality, Vol. 19 (1), pp. 42-59.

30.Seiders, K., Voss, G. B., Grewal, D. \& Godfrey, A. L. (2005). "Do Satisfied Customers Buy More? Examining Moderating Influences in a Retailing Context," Journal of Marketing, Vol. 69 (4), pp. 26-43.
31.Shapiro, T., Nieman-Gonder, J. M., Andreoli, N. A. \& Trimarco-Beta, D. (2006). "An Experimental Investigation of JusticeBased Service Recovery on Customer Satisfaction, Loyalty, and Word-of-Mouth Intentions," Psychological Reports, Vol. 99 (3), pp. 864-878.

32.Smith, A. K. \& Bolton, R. N. (1998). "An Experimental Investigation of Service Failure and Recovery: Paradox or Peril?," Journal of Service Research, Vol. 1 (1), pp. 65-81.

33.Smith, A. K., Bolton, R. N. \& Wagner, J. (1999). "A Model of Customer Satisfaction with Service Encounters Involving Failure and Recovery," Journal of Marketing Research, Vol. 36 (3), pp. 356-372.

34.Tax, S. S., Brown, S. W. \& Chandrashekaran, M. (1998). "Customer Evaluations of Service Complaint Experiences: Implications for Relationship Marketing," Journal of Marketing, Vol. 62 (2), pp. 60-76.

35.Weun, S., Beatty, S. E. \& Jones, M. A. (2004). "The Impact of Service Failure Severity on Service Recovery Evaluations and Post-Recovery Relationships," Journal of Services Marketing, Vol. 18 (2), pp. 133146.

36.White, K. \& Dahl, D. W. (2006). "To Be or Not Be? The Influence of Dissociative Reference Groups on Consumer Preferences," Journal of Consumer Psychology, Vol. 16 (4), pp. 404-414.

37.Zeithaml, V. A., Berry, L. L. \& Parasuraman, A. (1993). "The Nature and Determinants of Customer Expectations of Service," Journal of the Academy of Marketing Science, Vol. 21 (1), pp. 1-12. 